\title{
SVEIKESNĖ VISUOMENĖ KLAIPĖDOS RAJONE - SUAUGUSIŲJŲ GYVENSENA PER 10 METŲ PAGERĖJO
}

\author{
Neringa Tarvydiene் $\dot{ }^{1}$, Monika Steponkienè ${ }^{2}$ \\ ${ }^{1}$ Klaipédos rajono savivaldybès visuomenès sveikatos biuras, Klaipédos universitetas, \\ ${ }^{2}$ Klaipédos rajono savivaldybès visuomenès sveikatos biuras
}

Raktažodžiai: gyvensena, socioekonominiai rodikliai, sveikatos netolygumai, pokyčiai.

\section{Santrauka}

Tyrimo tikslas - nustatyti Klaipedos rajono suaugusiųjų gyventojų sveikos gyvensenos pokyčius per 10 metų.

Metodai. Klaipėdos rajono savivaldybės visuomenès sveikatos biuras nuo $2007 \mathrm{~m}$. sistemingai vykdo savo suaugusiųu gyventojų gyvensenos tyrimus $(2011 \mathrm{~m}$., 2014 m.). 2018 m. visos Lietuvos mastu buvo vykdomas suaugusiujų gyventojų gyvensenos tyrimas, kurį koordinavo Higienos institutas, o anketinę apklausą Klaipėdos rajone vykdè Klaipėdos rajono savivaldybès visuomenès sveikatos biuras. Apklausa kaimo ir miesto teritorijose buvo vykdoma skirtingai pagal metodologiją. Tyrimo populiacija - 18 metų amžiaus ir vyresni asmenys. Tyrimo imtis buvo apskaičiuota atsižvelgiant ị populiacijos dydị, pasirinkus 5 proc. paklaidą ir 95 proc. tikimybę. Surinkti anketinès apklausos duomenys analizuoti SPSS 17.0 statistiniu programų paketu.

Rezultatai. Žalingų ịpročių pokyčiai. 2018 m., palyginus su 2011 m., kasdien ir retkarčiais rūkančiųu sumažèjo nuo 59,9 proc. iki 29,1 proc. Vyrai rūko daugiau nei moterys ( $p<0,0001$ ir $p<0,05)$. Pradini, pagrindinị išsilavinimą turintys asmenys daugiau rūko nei respondentai, turintys aukštajị išsilavinimą ( $<<0,05$ ir p<0,0001). 2018 m., palyginus su 2014 m., bet kokio alkoholinio gerimo vartojimas du ir daugiau kartų per savaitę sumažejo 18,9 proc.

Mitybos įpročių pokyčiai. 2018 m. daugiau nei pusė apklaustujų paprastai pusryčiauja ir tai yra 42,5 proc. daugiau nei 2014 m. (p<0,0001). 2018 m., palyginus su 2014 m., šviežių daržovių vartojimas mažiausiai 3 kartus per savaitę padidejo 33,5 proc. $(\mathrm{p}<0,0001)$. Moterys daugiau nei vyrai valgo šviežias daržoves $(\mathrm{p}<0,05)$. Aukštajị išsilavinimą turintys asmenys daugiau vartoja šviežias daržoves nei turintys vidurinị ar pradini, pagrindinị išsilavinimą ( $\mathrm{p}<0,0001$ ir $\mathrm{p}<0,05)$. Fizinio aktyvumo pokyčiai. $2018 \mathrm{~m}$., palyginus su 2007 m., fizinis aktyvumas mažiausiai 4 kartus per savaitę padidejo nuo 21,9 proc. iki 50,7 proc. $(p<0,0001)$. Vyrai yra aktyvesni nei moterys $(p<0,05$ ir $\mathrm{p}<0,0001)$.

Sveikatos pokyčiai. Kas antras apklaustas gyventojas savo sveikatą vertina gerai ir tai 27,4 proc. daugiau nei 2011 metais $(p<0,0001)$. Aukštajị išsilavinimą turintys asmenys savo sveikatą vertina geriau nei respondentai, kurie turi pradinị, pagrindinị išsilavinimą $(p<0,05)$. Daugiau dirbantys asmenys savo sveikatą vertina gerai nei bedarbiai, studentai, moksleiviai, pensininkai, namų šeimininkès $(\mathrm{p}<0,05)$.

Išvados. Per 10 metų Klaipèdos rajone vykdyta visuomenès sveikatos kartu su kitais sektoriais veikla teigiamai veikia gyventojų sveikos gyvensenos pokyčius.

\section{Ivadas}

Gyvensena ir elgsena labiausiai nulemia žmogaus sveikatos būklę [1-2]. Lietuvos sveikatos $2014-2025 \mathrm{~m}$. strategijos tikslas yra pasiekti, kad $2025 \mathrm{~m}$. šalies gyventojai būtų sveikesni ir pailgètų jų gyvenimo trukmè, pagerètų gyventojų sveikata ir sumažetų sveikatos netolygumai [3]. Lietuvos Respublikos sveikatos apsaugos ministro $2014 \mathrm{~m}$. liepos 16 d. Nr. V-815 patvirtintame Sveikatos netolygumu mažinimo Lietuvoje 2014-2023 m. veiksmų plane sveikatos netolygumai apibrèžiami kaip „,diferenciacija tarp žmonių pagal sveikatos būklès (mirtingumo, būsimo gyvenimo trukmès rodikliai) skirtumus ir (ar) nevienodą sveikatos priežiūros paslaugų prieinamumą, kurị sąlygoja gyvenamoji vieta, pajamos ir kitos priežastys" [4]. Remiantis 2017 m. atliktu Eurobarometro tyrimu, 29 proc. 15 m. ir vyresnio amžiaus Lietuvos gyventojų yra rūkantys [5]. Pagal RARHA SEAS 2016 m. atliktą tyrimą, Lietuvoje 31,1 proc. 18-64 m. asmenų bent kartą per savaitę vartojo alkoholinius gèrimus [6]. Remiantis $2016 \mathrm{~m}$. bendrovès „Spinter tyrimai“ atliktu Lietuvos gyventojų fizinio aktyvumo tyrimu, 15 proc. 15-74 
m. amžiaus respondentų mankštinasi mažiausiai 3 kartus per savaitę [7].

Klaipėdos rajono savivaldybe išsiskiria iš visų savivaldybių Lietuvoje kaip viena pirmujjų ịsteigusių visuomenès sveikatos biurą (nuo 2007 metų), sistemingai dirbanti gerinant sąlygas gyventojų sveikatos stiprinimui. Visi pokyčiai rajone pradèti planuoti remiantis 2007 metų tyrimo rezultatais ir kas trejus metus vertinti pokyčiai. Sprendimai susiję su gyventojų sveikatos stiprinimo prioritetais, veiklomis pirma buvo priimami politiniu lygmeniu, suderinami su kitais sektoriais, atsižvelgiama ị nacionalinius prioritetus ir priimamus sprendimus. Paskutinį kartą Klaipėdos rajono savivaldybės taryba sveikatinimo veiklos prioritetus patvirtino 2015-2018 metams - tai fizinio aktyvumo, sveikos mitybos skatinimas, rūkymo ir alkoholio vartojimo mažinimas, siekiant stiprinti savivaldybės gyventojų sveikatą bei mažinti sveikatos netolygumus ( $2015 \mathrm{~m}$. gegužès $28 \mathrm{~d}$. sprendimas Nr. T11-155) [8]. Klaipedos rajono savivaldybès visuomenès

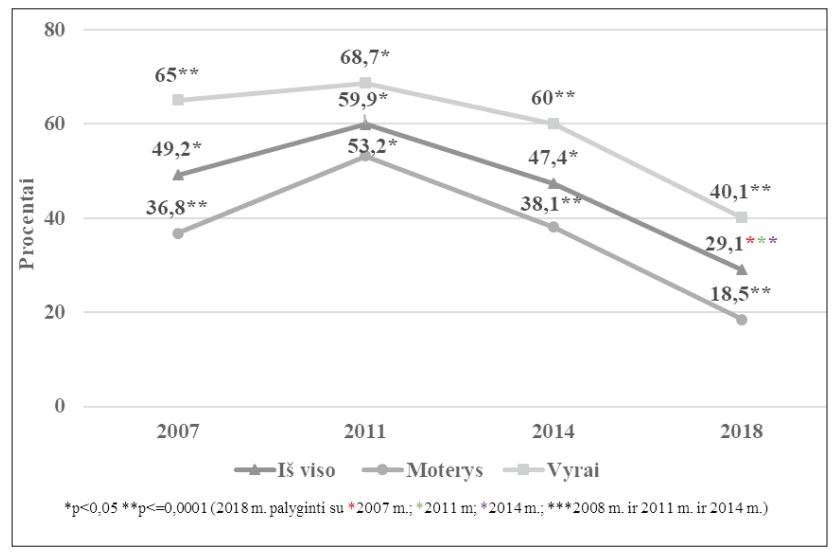

1 pav. Respondentų, kurie kasdien ir retkarčiais rūko, pasiskirstymas pagal lytị (proc.).

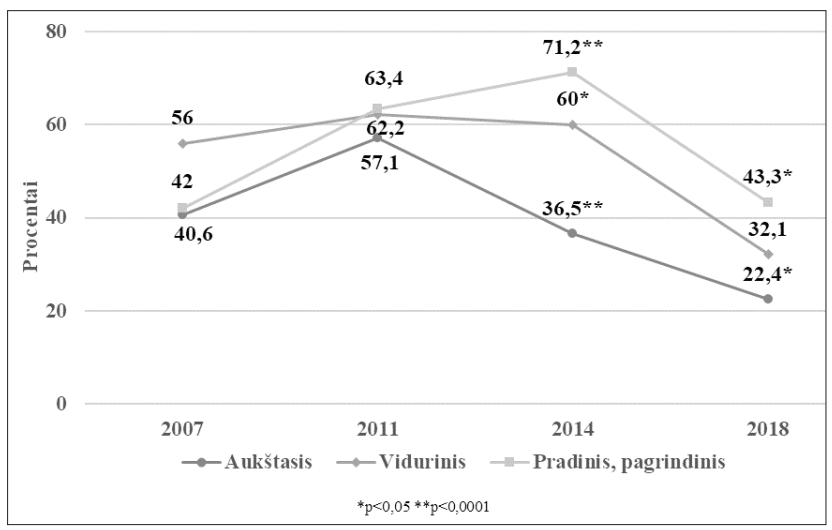

2 pav. Respondentų, kurie kasdien ir retkarčiais rūko, pasiskirstymas pagal išsilavinimą (proc.). sveikatos biuro sistemingai vykdomi suaugusiujų gyventojų gyvensenos tyrimai padeda ịvertinti visuomenès sveikatos priežiūros paslaugų, orientuotų ị suaugusius gyventojus ir vietinès sveikatos politikos, nukreiptos ị suaugusiujų gyventojų sveikatos gerinimą, efektyvumą.

Tyrimo tikslas - nustatyti Klaipédos rajono suaugusiujų gyventojų sveikos gyvensenos pokyčius per 10 metų.

\section{Tyrimo medžiaga ir metodai}

Klaipėdos rajono savivaldybès visuomenès sveikatos biuras nuo $2007 \mathrm{~m}$. sistemingai vykdo savo suaugusiujų gyventoju gyvensenos tyrimus (2011 m., 2014 m.). 2018 metais visos Lietuvos mastu buvo vykdomas suaugusiujų gyventojų gyvensenos tyrimas, kurị koordinavo Higienos institutas, o apklausas atliko savivaldybių visuomenès sveikatos biurų specialistai. Nuo balandžio mėnesio $17 \mathrm{~d}$. iki gegužès mènesio $25 \mathrm{~d}$. suaugusiujų gyventojų gyvensenos tyrimo apklausa vyko Klaipėdos rajono savivaldybejje. Apklausa kaimo ir miesto teritorijose buvo vykdoma skirtingai pagal

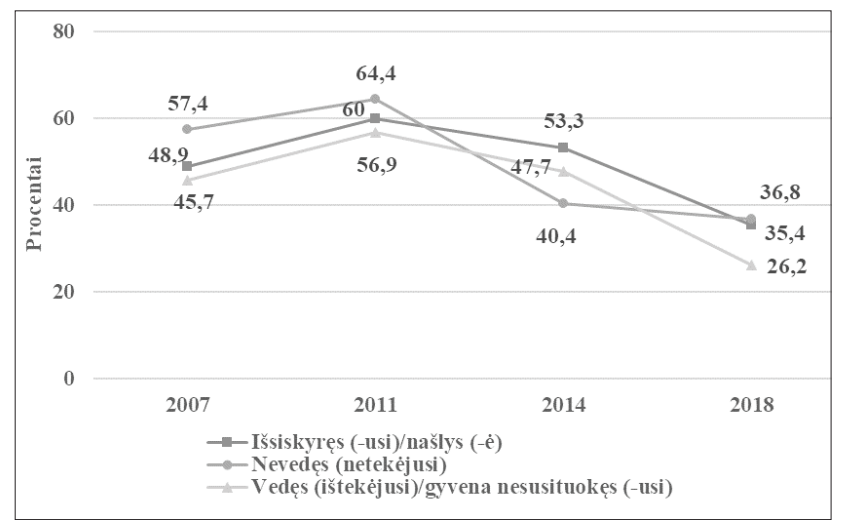

3 pav. Respondentų, kurie kasdien ir retkarčiais rūko, pasiskirstymas pagal šeiminę padètị (proc.).

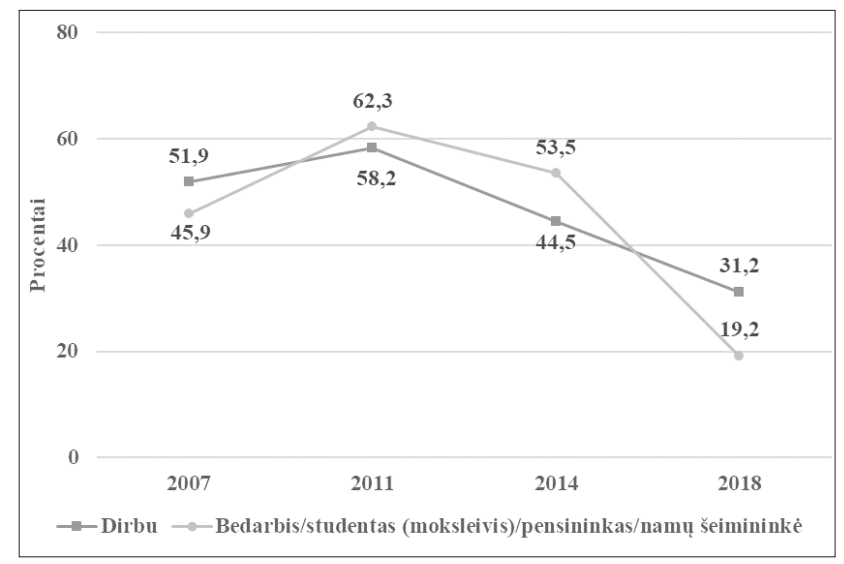

4 pav. Respondentų, kurie kasdien ir retkarčiais rūko, pasiskirstymas pagal pagrindinị užsièmimą (proc.). 
metodologiją. Gargžduose apklausai vykdyti buvo sudaromas abėcèlinis gatvių sąrašas ir, naudojant atsitiktinių skaičių generatorių, atrenkamos gatvės. Atrinktose gatvėse buvo pasirenkami namai su nelyginiais numeriais. Jei pasirinktas namas buvo daugiabutis, tuomet jame pasirinktas kas antras nelyginis butas. Kaimuose ir miesteliuose atsitiktinai buvo pasirenkama gatvė ir aplankomas kiekvienas namas. Daugiabučiuose namuose pasirinkti nelyginiai butai. Kiekviename name ar bute respondentas atrenkamas atsitiktinai, vadovaujantis ,paskutinio gimtadienio“ taisykle, t. y. jei name gyvena daugiau nei vienas 18 metų ir vyresnis asmuo, atrenkamas tas, kuris gimtadienị švente paskutinis.

Tyrimo populiacija - 18 metų amžiaus ir vyresni asmenys. Tyrimo imtis buvo apskaičiuota atsižvelgiant i t populiacijos dydi, pasirinkus 5 proc. paklaidą ir 95 proc. tikimybę. $2007 \mathrm{~m}$. tyrime dalyvavo 387 asmenys, $2011 \mathrm{~m}$. - 386, 2014 m. - 394, 2018 m. - 419 suaugusiujų gyventojų. Tyrimo metu apklausta 51,6 proc. moterų ir 48,4 proc. vyrų. Pagal

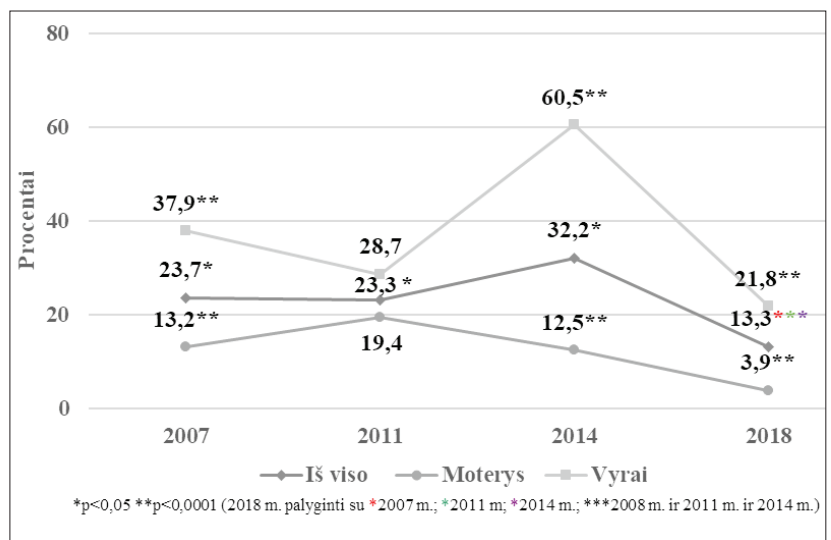

5 pav. Respondentų, kurie bet kokį alkoholinį gėrimą vartoja du ir daugiau kartų per savaitę, pasiskirstymas pagal lytị (proc.).

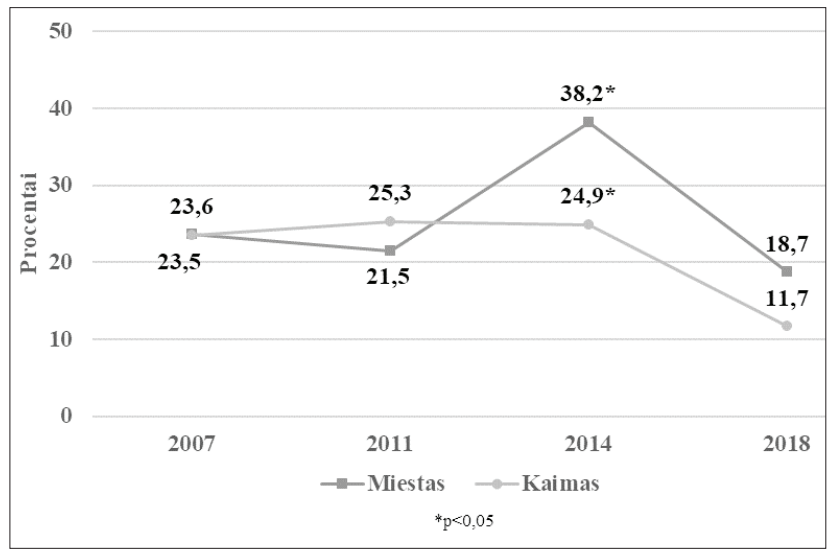

6 pav. Respondentų, kurie bet kokị alkoholinị gèrimą vartoja du ir daugiau kartų per savaitę, pasiskirstymas pagal gyvenamąją vietą (proc.). gyvenamają vietą 55,1 proc. respondentų sudaré miestelio gyventojai, miesto - 27,7 proc., kaimo - 17,2 proc. Daugiausia apklausta 45-54 metų amžiaus gyventojų.

Surinkti anketinès apklausos duomenys buvo analizuo-

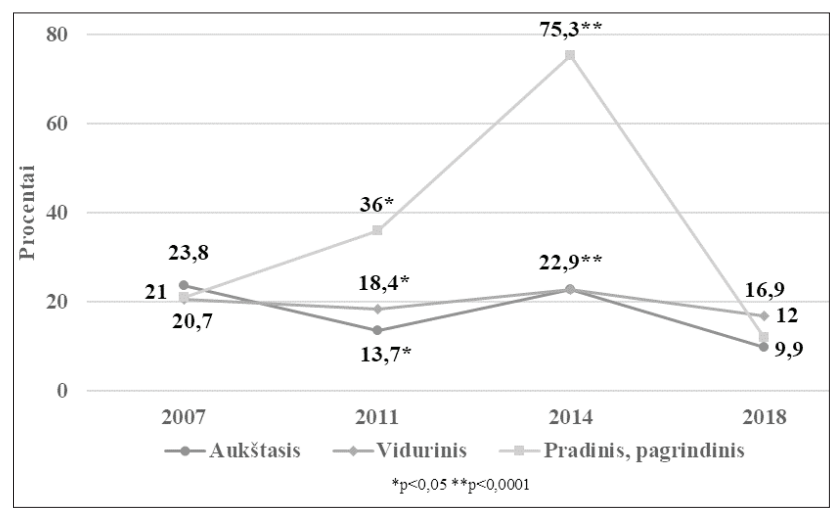

7 pav. Respondentų, kurie bet kokị alkoholinị gèrimą vartoja du ir daugiau kartų per savaitę, pasiskirstymas pagal išsilavinimą (proc.).

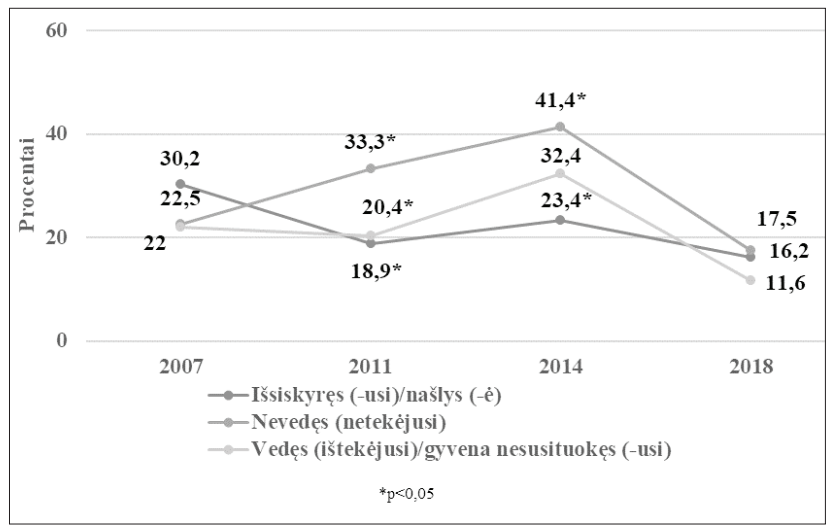

8 pav. Respondentų, kurie bet kokị alkoholinị gėrimą vartoja du ir daugiau kartų per savaitę, pasiskirstymas pagal šeiminę padèti (proc.).

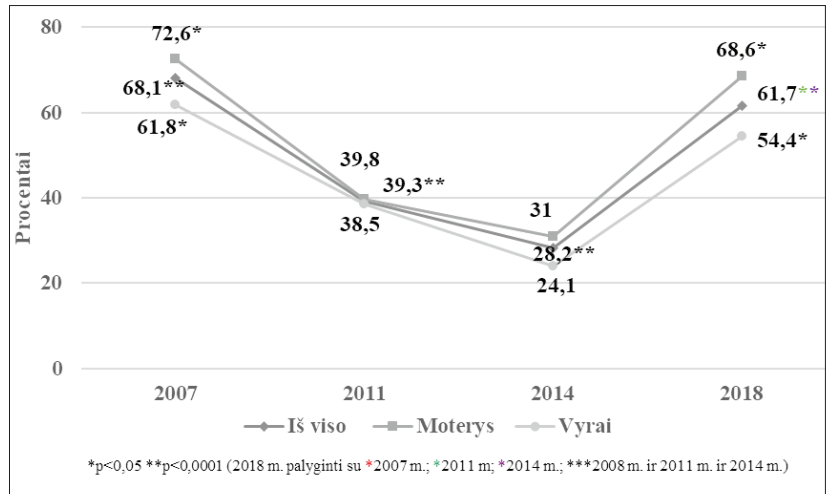

9 pav. Respondentų, kurie mažiausiai 3 kartus per savaitę vartoja šviežias daržoves, pasiskirstymas pagal lytị (proc.). 
jami SPSS 17.0 statistiniu programų paketu ir „Ms Excel“ programa. Duomenų analizejje taikytas Chi kvadrato kriterijus. Skirtumas tarp grupių laikytas statistiškai reikšmingu, kai $\mathrm{p}<0,05$.

\section{Tyrimo rezultatai ir jų aptarimas}

Rūkymo pokyčiai (kasdien ir retkarčiais). 2018 m., palyginus su 2011 m., kasdien ir retkarčiais rūkančiųjų sumažèjo nuo 59,9 proc. iki 29,1 proc. $(\mathrm{p}<0,0001)$. Vyrai rūko daugiau nei moterys ( $<<0,0001$ ir $p<0,05)$. 2018 m., palyginus su 2007 m., sumažejo rūkymo skirtumas tarp vyrų ir moterų (1 pav.). 2018 m., palyginus su 2007 m., padidèjo rūkymo skirtumas tarp miesto ir kaimo gyventojų. Nuo 2011 miesto gyventojai kasdien ir retkarčiais rūko mažiau $(\mathrm{p}<=0,0001)$.

Pradinị, pagrindinị išsilavinimą turintys asmenys daugiau rūko kasdien ir retkarčiais nei aukštajj išsilavinimą turintys $(p<0,05$ ir $p<0,0001) .2018$ m., palyginus su 2007 m., sumažèjo rūkymo skirtumas tarp aukštaji ir vidurinį išsilavinimą

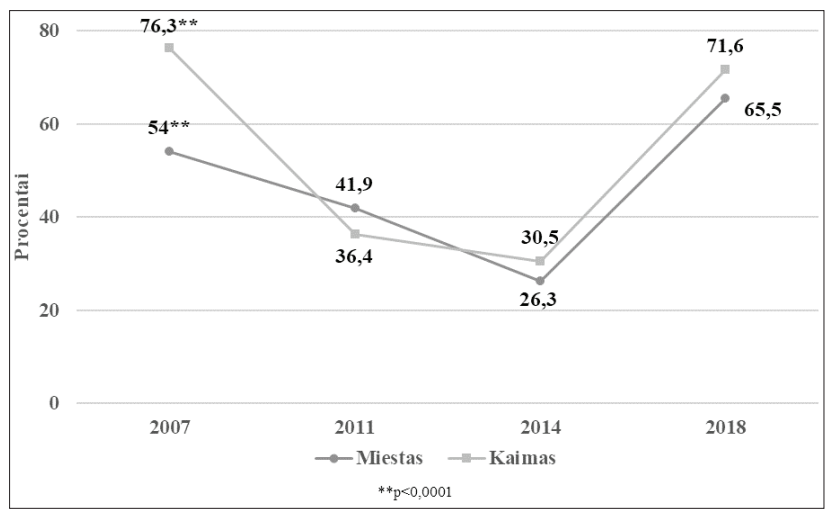

10 pav. Respondentų, kurie mažiausiai 3 kartus per savaitę vartoja šviežias daržoves, pasiskirstymas pagal gyvenamają vietą (proc.).

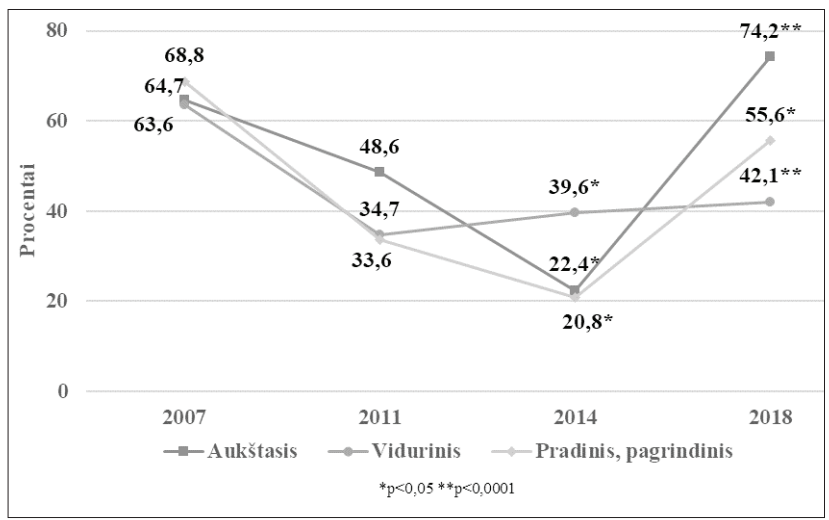

11 pav. Respondentų pasiskirstymas pagal tai, kurie mažiausiai 3 kartus per savaitę vartoja šviežias daržoves, pagal išsilavinimą (proc.) turinčių asmenų, tačiau padidèjo skirtumas tarp aukštajį ir pradinị, pagrindinị išsilavinimą turinčių asmenų (2 pav.).

2018 m., palyginus su 2007 m., sumažèjo rūkymo skirtumas tarp išsiskyrusių, našlių ir nevedusių, netekejjusių, tačiau padidèjo skirtumas tarp išsiskyrusių, našlių ir vedusių,

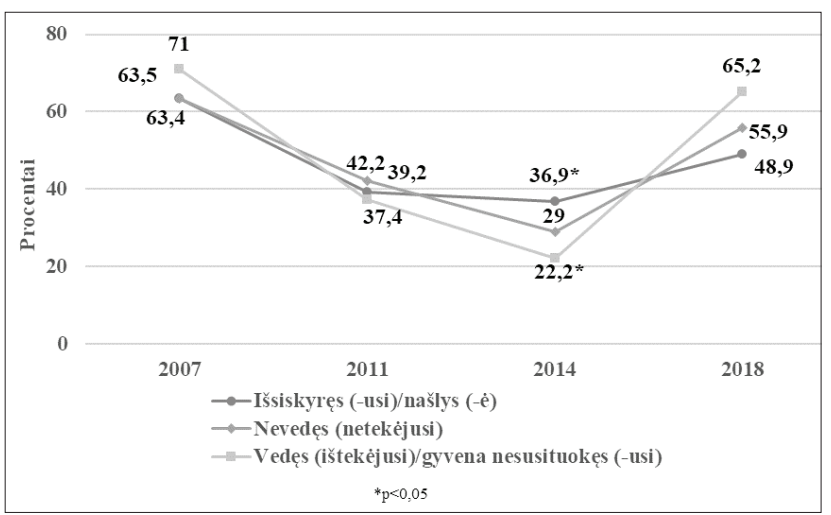

12 pav. Respondentų, kurie mažiausiai 3 kartus per savaitę vartoja šviežias daržoves, pasiskirstymas pagal šeiminę padètị (proc.).

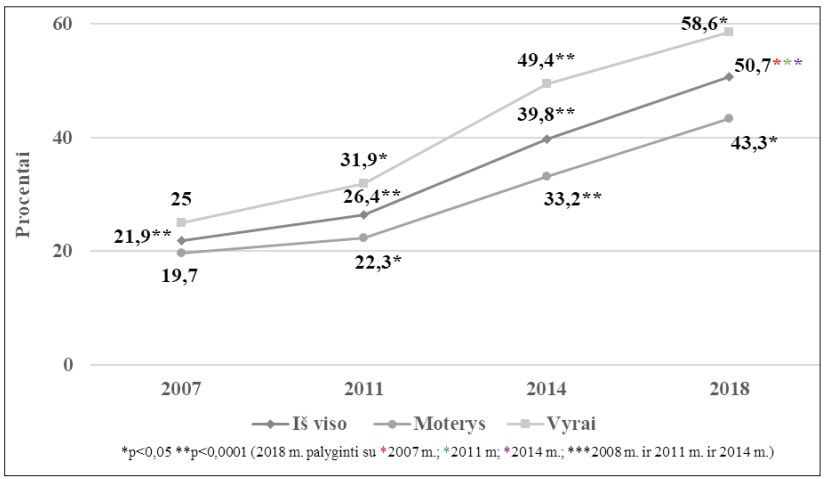

13 pav. Respondentų, kurie mažiausiai 4 kartus per savaitę $30 \mathrm{~min}$. užsiima energinga fizine veikla, pasiskirstymas pagal lytị (proc.).

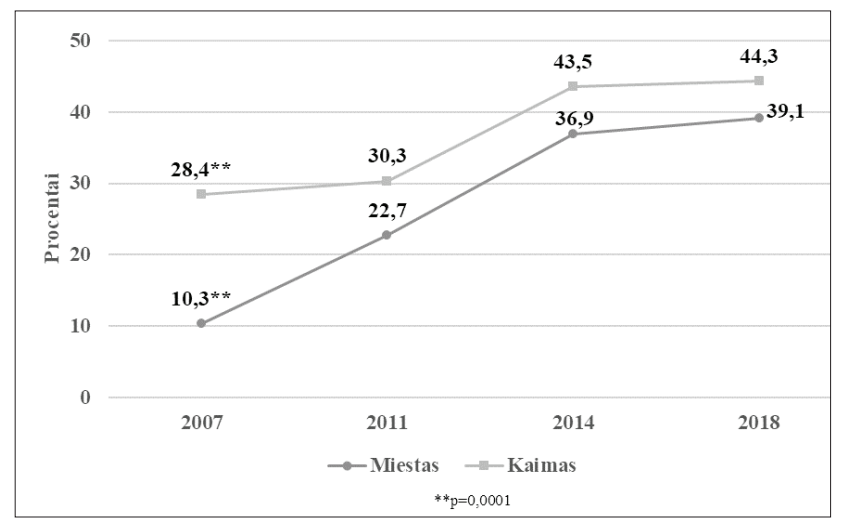

14 pav. Respondentų, kurie mažiausiai 4 kartus per savaitę 30 min. užsiima energinga fizine veikla, pasiskirstymas pagal gyvenamąją vietą (proc.). 
ištekèjusių, gyvenančių nesusituokus. Nuo 2011 m. mažiau rūko kasdien ir retkarčiais išsiskyrę, našliai ir vedę, ištekèjusios, gyvenantys nesusituokę ( $<<0,05$ ir $\mathrm{p}<0,0001$ ) ( 3 pav.).

2018 m., palyginus su 2007 m., padidejo rūkymo skirtumas tarp dirbančių ir bedarbių, studentų, moksleivių, pensininkų, namų šeimininkių. Nuo 2011 m. mažiau kasdien ir retkarčiais rūko tiek dirbantys, tiek bedarbiai, studentai, moksleiviai, pensininkai, namų šeimininkès $(p<0,0001)$ (4 pav.).

Pastaba: $2018 \mathrm{~m}$. duomenys per paskutines $30 \mathrm{~d}$.

Bet kokio alkoholio vartojimo pokyčiai (du ir daugiau kartụ per savaitę). 2018 m., palyginus su 2014 m., bet kokio alkoholinio gerimo vartojimas du ir daugiau kartų per savaitę sumažejo 18,9 proc. (p<0,0001). 2018 m., palyginus su 2007 m., alkoholio vartojimo skirtumas sumažejo tarp vyrų ir moterų ( 5 pav.).

2018 m., palyginus su 2007 m., padidèjo alkoholio vartojimo skirtumas tarp miesto ir kaimo gyventojų. Nuo 2014

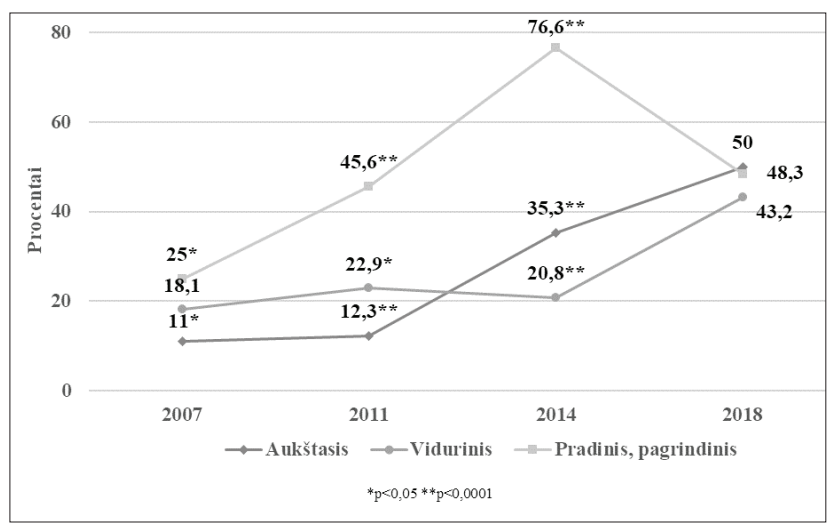

15 pav. Respondentų, kurie mažiausiai 4 kartus per savaitę 30 min. užsiima energinga fizine veikla, pasiskirstymas pagal išsilavinimą (proc.).

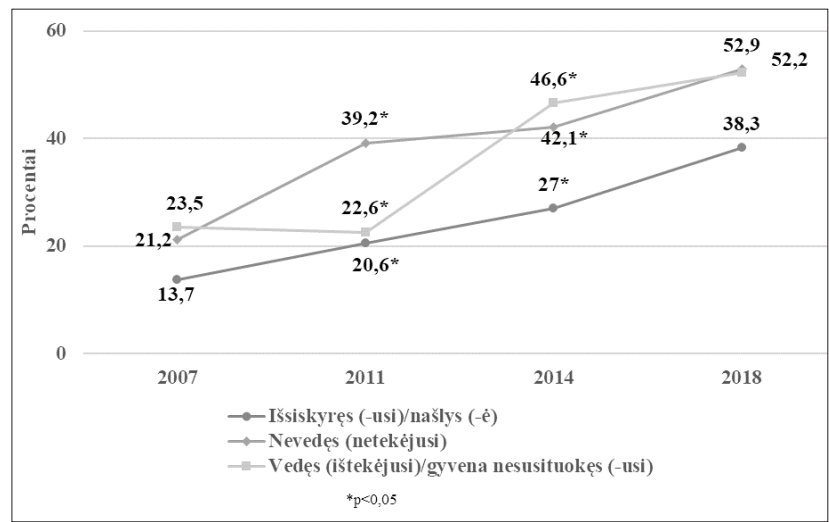

16 pav. Respondentų, kurie mažiausiai 4 kartus per savaitę 30 min. užsiima energinga fizine veikla, pasiskirstymas pagal šeiminę padètị (proc.). m. miesto ir nuo $2011 \mathrm{~m}$. kaimo gyventojai mažiau vartoja alkoholinių gėrimų du ir daugiau kartų per savaitę $(\mathrm{p}<0,05)$ (6 pav.).

2018 m., palyginus su 2007 m., padidejjo alkoholio vartojimo skirtumas tarp aukštajị ir vidurinị išsilavinimą turinčių asmenų, tarp pradinị, pagrindinị ir vidurinị išsilavinimą turinčių respondentų. Nuo 2014 m. aukštajji ir pradini, pagrindinị išsilavinimą turintys asmenys mažiau vartoja alkoholinių gérimų du ir daugiau kartų per savaitę $(\mathrm{p}<0,05$ ir $\mathrm{p}<0,0001)$ (7 pav.).

2018 m., palyginus su 2007 m., padidejjo alkoholio vartojimo skirtumas tarp nevedusių, netekèjusių ir vedusių, ištekejjusių, gyvenančių nesusituokus. Nuo 2014 m. nevedę, netekejjusios ir vedę, ištekejjusios, gyvenantys nesusituokę mažiau vartoja alkoholinių gèrimų du ir daugiau kartų per savaitę ( $\mathrm{p}<0,05$ ir $\mathrm{p}<0,0001)$ ( 8 pav.).

2018 m., palyginus su 2007 m., sumažèjo alkoholio vartojimo skirtumas tarp dirbančių ir bedarbių, studentų, moksleivių, pensininkų, namų šeimininkių. Nuo 2014 m. tiek dirbantys, tiek bedarbiai, studentai, moksleiviai, pen-

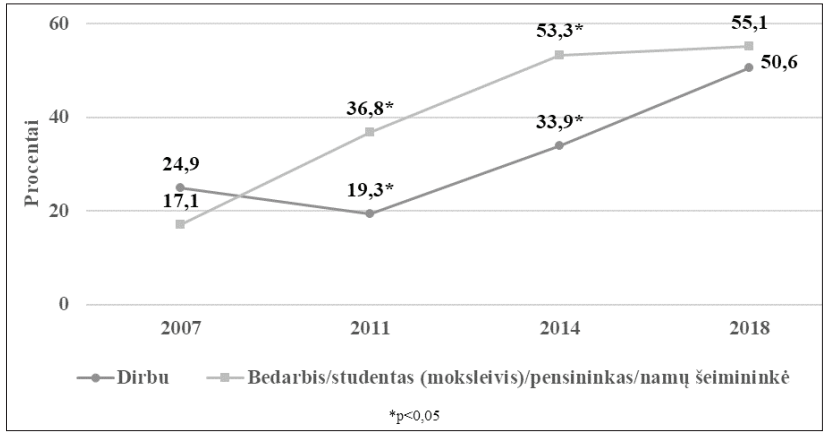

17 pav. Respondentų, kurie mažiausiai 4 kartus per savaitę 30 min. užsiima energinga fizine veikla, pasiskirstymas pagal pagrindinị užsièmimą (proc.).

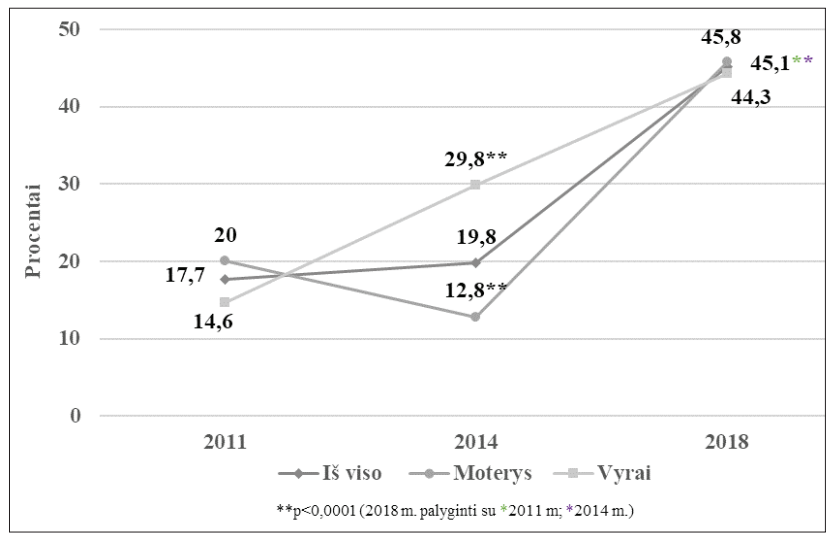

18 pav. Respondentų, kurie gerai vertina savo sveikatos būklę, pasiskirstymas pagal lytị (proc.). 
sininkai, namų šeimininkès mažiau vartoja alkoholinių gèrimų du ir daugiau kartų per savaitę $(\mathrm{p}<0,0001$ ir $\mathrm{p}<0,05)$

Pastaba: $2018 \mathrm{~m}$. duomenys per paskutines $30 \mathrm{~d}$.

Daržovių vartojimo pokyčiai (mažiausiai 3 kartus per savaitę). 2018 m., palyginus su 2014 m., šviežių daržovių vartojimas mažiausiai 3 kartus per savaitę padidejo 33,5 proc. $(\mathrm{p}<0,0001)$. Moterys daugiau nei vyrai valgo šviežias daržoves 3 ir daugiau kartų per savaitę $(p<0,05)(9$ pav.).

2018 m., palyginus su 2007 m., šviežių daržovių vartojimo skirtumas sumažejo tarp miesto ir kaimo gyventojų. Nuo $2014 \mathrm{~m}$. tiek miesto, tiek kaimo gyventojai daugiau valgo daržoves mažiausiai 3 kartus per savaitę $(\mathrm{p}<0,0001)(10$ pav.).

Aukštajį išsilavinimą turintys asmenys daugiau vartoja šviežias daržoves 3 ir daugiau kartų per savaitę, nei turintys vidurinị ar pradinį, pagrindinị išsilavinimą ( $\mathrm{p}<0,0001$ ir $\mathrm{p}<0,05)$ (11 pav.).

2018 m., palyginus su 2007 m., padidejo daržovių valgymo skirtumas tarp išsiskyrusių, našlių ir nevedusių, netekejjusių, tarp išsiskyrusių, našlių ir vedusių, ištekejjusių. Nuo 2014 m. nevedę, netekejjusios daugiau vartoja šviežias daržoves 3 ir daugiau kartų per savaitę $(\mathrm{p}<0,05)(12$ pav.).

Fizinio aktyvumo pokyčiai (mažiausiai 4 kartus per savaitę). 2018 m., palyginus su 2007 m., fizinis aktyvumas mažiausiai 4 kartus per savaitę padidèjo nuo 21,9 proc. iki 50,7 proc. $(\mathrm{p}<0,0001)$. Padidèjo fizinio aktyvumo skirtumas tarp vyrų ir moterų, vyrai sportuoja daugiau 4 ir daugiau kartų per savaitę nei moterys ( $\mathrm{p}<0,05$ ir $\mathrm{p}<0,0001)$ (13 pav.).

Sumažejo fizinio aktyvumo skirtumas tarp miesto ir kaimo gyventojų. Nuo 2007 m. tiek miesto, tiek kaimo gyventojų, kurie mankštinasi mažiausiai 4 kartus per savaitę, daugèja ( $<<0,0001$ ir $\mathrm{p}<0,05)(14 \mathrm{pav}$.).

2018 m., palyginus su 2007 m., sumažèjo fizinio aktyvumo skirtumas tarp aukštajị ir pradinị, pagrindinị išsilavinimą turinčių asmenų. Nuo 2007 m. aukštajį išsilavinimą

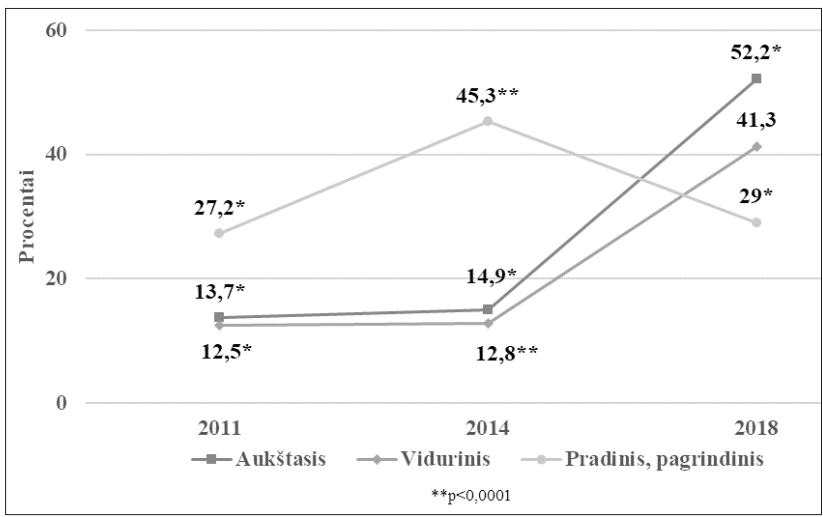

19 pav. Respondentų, kurie gerai vertina savo sveikatos būklę, pasiskirstymas pagal išsilavinimą (proc.). turintys asmenys daugiau sportuoja 4 ir daugiau kartu per savaitę $(\mathrm{p}<0,05)(15$ pav. $)$.

2018 m., lyginant su 2007 m., padidèjo fizinio aktyvumo skirtumas tarp išsiskyrusių ir vedusių (ištekèjusių), bei tarp išsiskyrusių ir nevedusių (netekèjusių). 2018 m., palyginus su 2007 m., išsiskyrę (-usios), nevedę (netekèjusios) daugiau mankštinasi 4 ir daugiau kartų per savaitę $(\mathrm{p}<0,05$ ir $\mathrm{p}<0,0001)$ (16 pav.).

Nuo $2011 \mathrm{~m}$. dirbantys asmenys ir nuo $2007 \mathrm{~m}$. bedarbiai, studentai, moksleiviai, pensininkai (-ès), namų šeimininkès daugiau sportuoja 4 ir daugiau kartų per savaitę $(p<0,0001)$ (17 pav.).

Savo sveikatos vertinimo pokyčiai (savo sveikatą vertina gerai). $2018 \mathrm{~m}$. kas antras apklaustas gyventojas savo sveikatą vertina gerai ir tai 27,4 proc. daugiau nei 2011 metais (p<0,0001). 2018 m., palyginus su 2007 m., savo sveikatos vertinimo skirtumas sumažejo tarp vyrų ir moterų. Nuo $2014 \mathrm{~m}$. moterys ir nuo $2011 \mathrm{~m}$. vyrai savo sveikatą vertina geriau $(\mathrm{p}<0,05$ ir $\mathrm{p}<0,0001)(18$ pav.). Nuo 2011 $\mathrm{m}$. tiek miesto, tiek kaimo gyventojai savo sveikatą vertina geriau $(\mathrm{p}<0,0001)$.

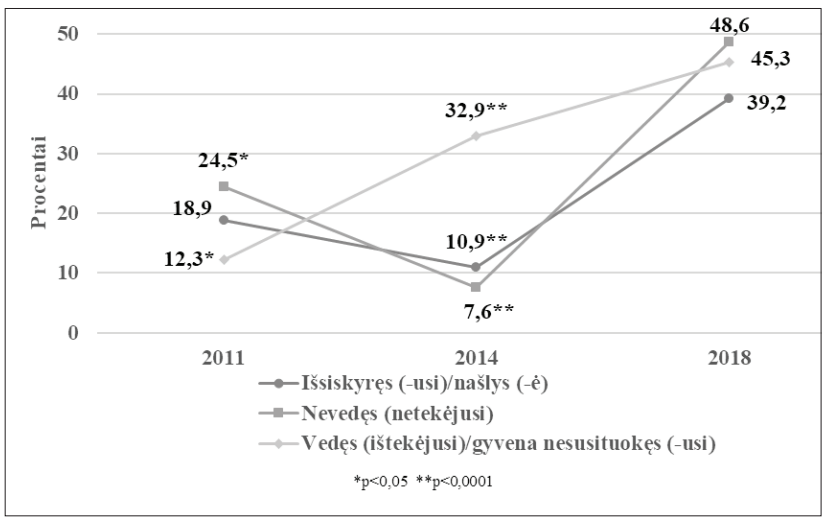

20 pav. Respondentų, kurie gerai vertina savo sveikatos būklę, pasiskirstymas pagal šeiminę padètị (proc.).

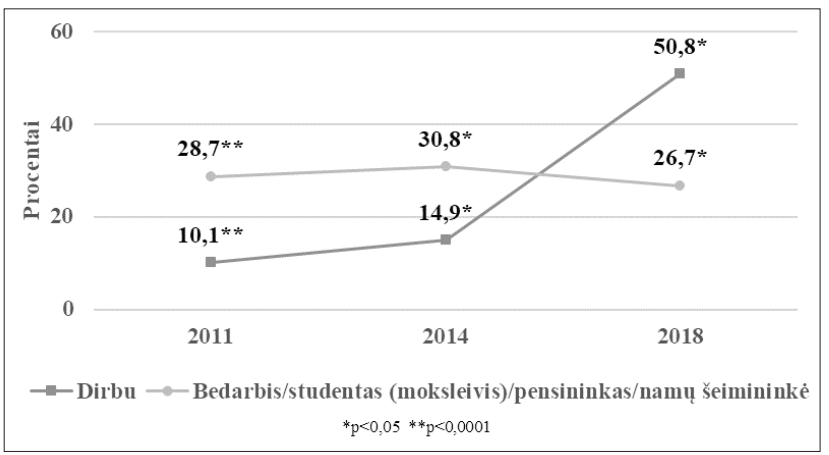

21 pav. Respondentų, kurie gerai vertina savo sveikatos būklę, pasiskirstymas pagal pagrindinị užsièmimą (proc.). 
Aukštajji išsilavinimą turintys asmenys savo sveikatą vertina geriau nei respondentai, kurie turi pradini, pagrindini išsilavinimą $(\mathrm{p}<0,05)(19 \mathrm{pav}$.).

2018 m., palyginus su 2007 m., padidèjo savo sveikatos vertinimo skirtumas tarp išsiskyrusių, našlių ir nevedusių, netekejjusių, tačiau skirtumas sumažejo tarp nevedusių, netekejjusių ir vedusių, ištekejjusių, gyvenančių nesusituokus. Nuo 2014 m. išsiskyrę, našliai ir nevedę, netekejjusios geriau vertina savo sveikatą ( $<<0,0001)$. Nuo $2011 \mathrm{~m}$. daugiau vedusių, ištekejjusių, gyvenančiu nesusituokus savo sveikatą vertina gerai $(\mathrm{p}<0,05)(20 \mathrm{pav}$.$) .$

Dirbantys asmenys savo sveikatą vertina geriau nei bedarbiai, studentai, moksleiviai, pensininkai, namų šeimininkès $(\mathrm{p}<0,05)(21$ pav. $)$.

\section{Išvados}

1. Per 10 metų Klaipèdos rajone vykdyta visuomenès sveikatos kartu su kitais sektoriais veikla teigiamai veikia gyventojų sveikos gyvensenos pokyčius.

2. Klaipėdos rajone rūkančiụjų kasdien ir retkarčiais, vartojančiu alkoholinius gèrimus mažèja.

3. Klaipėdos rajone gerejja gyventojų mitybos ịpročiai: daugiau pusryčiaujančių ir valgančių šviežias daržoves asmenų. dèjo.

4. Klaipėdos rajone gyventojų fizinis aktyvumas padi-

5. Gyventojų, vertinančių savo sveikatą gerai, padaugèjo.

6. Egzistuoja rūkymo, alkoholinių gèrimų vartojimo, daržovių valgymo ịpročių, fizinio aktyvumo, savo sveikatos vertinimo netolygumai tarp suaugusių gyventojų pagal socioekonominius rodiklius - lytį, gyvenamają vietą, išsilavinimą, šeiminę padètí, užimtumą.

\section{Literatūra}

1. Mc Govern L, Miller G, Hughes-Cromwick P. Health policy brief: the relative contribution of multiple determinants to health outcomes. Health Affairs 2014; 4-5.

2. Valentienė J., Nedzinskiené L., Liuima V. ir kt. Sveikatos netolygumų stebėsena ir vertinimas. Vilnius, 2016; 6.

3. „Dèl Lietuvos sveikatos 2014-2025 metų programos patvirtinimo": Lietuvos Respublikos Seimo nutarimas 2014 m. birželio 26 d. Nr. XII-964.

4. „Dèl sveikatos netolygumų mažinimo Lietuvoje 2014-2023 m. veiksmų plano patvirtinimo“: Lietuvos Respublikos sveikatos apsaugos ministro $2014 \mathrm{~m}$. liepos $17 \mathrm{~d}$. ịsakymas Nr. V-815.

5. Attitudes of Europeans towards tobacco and electronic cigarettes. European Union 2017; 8.

6. Comparative monitoring of alcohol epidemiology across the EU. PARPA - The State Agency for Prevention of Alcohol Related Problems 2016; 76-77.

7. Lietuvos gyventojų fizinio aktyvumo tyrimas. Vilnius 2016; 7.
8. „Dèl Klaipėdos rajono savivaldybès sveikatinimo veiklos prioritetų 2015-2018 metams nustatymo": Klaipedos rajono savivaldybès tarybos $2015 \mathrm{~m}$. gegužès $28 \mathrm{~d}$. sprendimas Nr. T11-155.

\section{A HEALTHY SOCIETY IN KLAIPE்DA REGION - ADULT LIFESTYLE BY TEN YEARS IMPROVED N.Tarvydienė, M.Steponkienė}

Keywords: lifestyle, socio-economic indicators, health inequality, change.

Summary

The aim of the study - to determine the changes in healthy lifestyle of the adult population of Klaipeda region by ten years.

Methods. Public Health Bureau of Klaipeda District Municipality since 2007 systematically conducts lifestyle research of adult population $(2011,2014)$. In 2018 year a lifestyle survey of adults was performed in municipalities of Lithuanian, coordinated by the Hygiene Institute, and a survey in Klaipeda district was performed by Public Health Bureau of Klaipeda District Municipality. The survey in rural and urban areas was performed differently according to the methodology. The study population - persons 18 years and older. The survey sample was calculated by the size of the study population, with a 5 percent error and 95 percent probability. Survey data were analyzed by SPSS 17.0 statistical program.

Results. Changes in harmful habits. In 2018, compared to 2011, daily and occasionally smokers decreased from 59.9 percent to 29.1 percent. Mens smoke more than womens $(p<0.0001$ and $p<0.05)$. People with primary, basic education more smoke than respondents with higher education $(p<0.05$ and $p<0.0001)$. In 2018, compared to 2014 , the consumption of any alcoholic beverage two and more times a week decreased by 18.9 percent.

Changes in eating habits. In 2018 more than half of those surveyed usually have breakfast and this is 42.5 percent more than in 2014 ( $\mathrm{p}<0.0001$ ). In 2018, compared to 2014, the consumption of fresh vegetables at least 3 times a week increased by 33.5 percent $(p<0.0001)$. Womens eat more vegetables than mens $(p<0.05)$.

People with higher education more consume fresh vegetables than people with secondary or primary education $(p<0.0001$ and $\mathrm{p}<0.05)$.

Changes in physical activity. In 2018, compared to 2007, physical activity at least 4 times a week increased from 21.9 percent to 50.7 percent $(\mathrm{p}<0.0001)$. Mens are more active than womens $(\mathrm{p}<0.05$ and $\mathrm{p}<0.0001)$.

Health changes. Every second respondent evaluates his health well and this is 27.4 percent. more than in $2011(\mathrm{p}<0.0001)$. People with higher education value their health better than respondents with primary, basic education $(p<0.05)$. Workers value their health better than the unemployed, students, schoolchildren, retirees, housewives $(\mathrm{p}<0.05)$.

Conclusions. The activities of public health in cooperation with other sectors in Klaipéda district by ten years have had a positive effect on changes in healthy lifestyle of the population.

Correspondence to:

monika.steponkiene@visuomenessveikata.lt

Gauta 2019-05-16 